\title{
The Role of Metabolic Factors in Renal Cancers
}

\author{
Jacek Rysz ${ }^{1}$, Beata Franczyk ${ }^{1}$, Janusz Ławiński ${ }^{2}$, Robert Olszewski ${ }^{3,4}{ }^{(D}$ \\ and Anna Gluba-Brzózka ${ }^{1, *(\mathbb{D})}$ \\ 1 Department of Nephrology, Hypertension and Family Medicine, Medical University of Lodz, \\ 90-549 Lodz, Poland; jacek.rysz@umed.lodz.pl (J.R.); bfranczyk-skora@wp.pl (B.F.) \\ 2 Department of Urology, Institute of Medical Sciences, Medical College of Rzeszow University, \\ 35-055 Rzeszow, Poland; janlaw@poczta.onet.pl \\ 3 Department of Gerontology, Public Health and Education, National Institute of Geriatrics Rheumatology \\ and Rehabilitation, 02-106 Warsaw, Poland; robert.olszewski@me.com \\ 4 Department of Ultrasound, Institute of Fundamental Technological Research, Polish Academy of Sciences, \\ 02-106 Warsaw, Poland \\ * Correspondence: aniagluba@yahoo.pl
}

Received: 11 August 2020; Accepted: 25 September 2020; Published: 30 September 2020

\begin{abstract}
An increasing number of evidence indicates that metabolic factors may play an important role in the development and progression of certain types of cancers, including renal cell carcinoma (RCC). This tumour is the most common kidney cancer which accounts for approximately 3-5\% of malignant tumours in adults. Numerous studies indicated that concomitant diseases, including diabetes mellitus (DM) and hypertension, as well as obesity, insulin resistance, and lipid disorders, may also influence the prognosis and cancer-specific overall survival. However, the results of studies concerning the impact of metabolic factors on RCC are controversial. It appears that obesity increases the risk of RCC development; however, it may be a favourable factor in terms of prognosis. Obesity is closely related to insulin resistance and the development of diabetes mellitus type 2 (DM2T) since the adipocytes in visceral tissue secrete substances responsible for insulin resistance, e.g., free fatty acids. Interactions between insulin and insulin-like growth factor (IGF) system appear to be of key importance in the development and progression of RCC; however, the exact role of insulin and IGFs in RCC pathophysiology remains elusive. Studies indicated that diabetes increased the risk of RCC, but it might not alter cancer-related survival. The risk associated with a lipid profile is most mysterious, as numerous studies provided conflicting results. Even though large studies unravelling pathomechanisms involved in cancer growth are required to finally establish the impact of metabolic factors on the development, progression, and prognosis of renal cancers, it seems that the monitoring of health conditions, such as diabetes, low body mass index (BMI), and lipid disorders is of high importance in clear-cell RCC.
\end{abstract}

Keywords: renal cell carcinoma; obesity; insulin resistance; diabetes mellitus; lipid disorders

\section{Introduction}

An increasing number of evidence indicates that metabolic factors may play an important role in the development and progression of certain types of cancers [1]. The presence of metabolic syndrome has been shown to be associated with greater risk of prostate, liver, pancreatic, bladder, colorectal, cervical, and postmenopausal breast cancers [2-6]. Moreover, the prognosis of patients with cancers and concomitant metabolic syndrome has been suggested to be worse. Obese patients with prostate cancer were shown to be more likely to develop high-grade and aggressive cancer [7]. The impact of metabolic factors has also been shown in patients with renal cell carcinoma. 
Renal cell carcinoma (RCC) is the most common kidney cancer which accounts for approximately $3-5 \%$ of malignant tumours in adults and its incidence is still rising as an effect of modern lifestyle and high prevalence of comorbidities [8]. According to WHO estimations, RCC is the 6th most frequently diagnosed malignancy in men, the 10th commonest tumour in women, and the 13th commonest cause of cancer death [9]. The highest incidence of renal cell carcinoma is observed in North America and Europe [10]. Owing to the development of imaging technology and better healthcare, the frequency of detection of early-stage renal tumours has increased; however, a considerable percentage of patients have metastases in the lungs, liver, brain, or lymph nodes at the time of diagnosis [11,12]. Renal cell carcinoma belongs to a heterogeneous group of primary kidney adenocarcinomas originating from renal parenchyma, which comprises three histologically different types: clear cell (80-90\%), papillary (10-15\%), and chromophobe (4-5\%) [8]. The loss of von Hippel-Lindau (VHL) tumour suppressor accompanied by subsequent stabilization of hypoxia-inducible factor (HIF) responsible for extensive metabolic reprogramming is the most frequent cause of clear-cell renal cell carcinoma [13]. Obesity, smoking, and hypertension are among the lifestyle-associated risk factors of RCC present in up to $50 \%$ of cases $[10,14,15]$. Moreover, diabetes mellitus (DM) type 2 in women, high body mass index (BMI), and increased blood pressure in men, as well as elevated levels of triglycerides, were suggested to be independent RCC risk factors [16-18]. Numerous studies indicated that concomitant diseases, including DM and hypertension, as well as obesity, insulin resistance and lipid disorders, may also influence the prognosis and cancer-specific overall survival [19-21]. However, the results of studies concerning the impact of metabolic factors on RCC are conflicting. It remains unclear whether these factors alter the risk independently, or they interact to increase the risk of RCC. Irrespective of their manner of action, it seems that worse outcomes could be the result of the presence of metabolic factors per se.

\section{Obesity}

A growing number of studies have indicated that obesity is an independent risk factor of RCC [17]. A large quantitative summary analysis performed to assess the impact of obesity on the risk of renal cell cancer both in men and women demonstrated a relationship between metabolic syndrome and RCC, which was stronger in men with higher body mass index (BMI). It also revealed that the relative risk for both sexes was 1.07 (95\% confidence interval (CI): 1.05-1.09) per unit of increase in BMI (one unit corresponds to $3.1 \mathrm{~kg}$ for a man of average height and to $2.7 \mathrm{~kg}$ for a woman of average height) [22]. The meta-analysis of 24 cohort studies and nearly 9,000,000 participants confirmed weight-related increase in renal cancer risk. The risk of kidney cancer was increased by $35 \%$ in overweight participants and by $76 \%$ in obese subjects in comparison to normal weight participants, irrespective of the gender [23]. The impact of BMI on cancer risk was shown to be related to dose-response- $-1 \mathrm{~kg} / \mathrm{m}^{2}$ increase in BMI amplified the risk by $6 \%$ in men (relative risk $(R R)=1.06,95 \%$ CI: $1.05-1.08$ ) and by $5 \%$ in women ( $R R=1.05,95 \%$ CI: 1.04-1.06). Hu et al. [19] showed that overweight and obesity were considerably associated with greater RCC prevalence. A large study based on data from 1,110,835 adolescent males (16-19 years) examined for fitness for military service found a substantial excess risk associated with a body mass index of greater than $27.5 \mathrm{~kg} / \mathrm{m}^{2}$ compared to BMI less than $22.5 \mathrm{~kg} / \mathrm{m}^{2}$ (hazard ratio $(\mathrm{HR})=2.43,95 \%$ CI: 1.54-3.83, $p<0.0001)$ [24]. Authors suggested that the prevention of childhood obesity might be a promising tool for reducing the burden of renal cancer. Obesity may influence the risk of renal cancer via several mechanisms. The adipose tissue seems to be involved in the modulation of RCC risk. The adipose tissue, which is a key endocrine gland responsible for the biosynthesis and secretion of numerous hormones and cytokines (adipokines), becomes highly dysfunctional in consequence of weight gain [25]. According to studies, obesity and central fat distribution decrease serum adiponectin levels [26,27]. Adiponectin, which has been shown to play an anti-tumour role due to its anti-inflammatory and antiproliferative effects and antagonism to insulin resistance leading to the inhibition of tumour growth and angiogenesis, is mainly secreted by white adipose tissue. In vitro experiments confirmed that adiponectin hampered tumour growth through the activation of 
AMP-activated protein kinase (AMPK) and subsequent suppression of mammalian target of rapamycin (mTOR) pathways [28]. Moreover, Spyridopoulos et al. [29] demonstrated reverse association between serum adiponectin level and the risk of RCC. In turn, increased serum levels of leptin, which is also produced predominantly by white adipose tissue, have been found to be associated with RCC invasion and progression [30]. Numerous epidemiological studies have confirmed significant relationship between elevated leptin levels and increased risk of RCC as well as invasion, migration, and progression in RCC [31-33]. Some of them have indicated the association between diminished adiponectin levels and RCC tumour size [31,34]. Tumour proliferation promoted by leptin involves the activation of the extracellular signal-regulated kinases (ERK1/2) and Janus kinase/signal transducer and activator of transcription 3 (JAK/STAT3) signalling pathway, as well as the upregulation of vascular endothelial growth factor (VEGF) via hypoxia-inducible factor- $1 \alpha$ (HIF-1 $\alpha$ ) and nuclear factor-kappa B (NF-kB), which results in apoptosis inhibition and enhanced cancer cell proliferation [30,32,33,35]. The role of leptin in renal cell cancer development and progression was presented on Figure 1.

The increased risk of RCC development in obese patients has been also ascribed to deregulation of insulin (IN) and insulin-like growth factors (IGFs) signalling since these pathways are believed to be engaged in tumorigenesis and cancer progression [36]. Obese individuals were shown to have higher oestrogen levels which may promote the carcinogenic effect of IGF [37]. Finally, obesity is associated with enhanced secretion of high amounts of pro-inflammatory cytokines, stimulating a low-grade chronic inflammatory state [25]. Growing adipose tissue also produces high levels of acute phase reactants, including serum amyloid A (SAA), C-reactive protein (CRP,) retinol-binding protein 4 (RBP4), and other proteins such as vascular cell adhesion molecule 1 (VCAM1), intercellular adhesion molecule 1 (ICAM1), and chemokine C-X-C motif ligand 10 (CXCL10) [38,39]. The presence of chronic inflammatory state can promote cancer initiation, progression, malignant conversion, invasion, and metastasis; alter host immunosurveillance; and affect local tumour microenvironment directly and distant tumour cells through the systemic effects of endocrine signals [40,41]. According to studies, inflammatory cytokines enhance the risk of recurrence following RCC surgical resection and are also associated with poor prognosis [42].

The results of numerous studies indicate that obesity increases the risk of RCC development; however, it also seems to be a favourable factor in terms of prognosis. Waalkes et al. [43] observed higher tumour grade and rate of metastasis at diagnosis in patients with lower BMI, but only those with organ-confined RCC. They indicated that the risk of cancer-related death was also significantly lower in overweight patients: median 5-year tumour-specific survival rate was $63.8 \%$ in patients with a BMI below $25 \mathrm{~kg} / \mathrm{m}^{2}, 70.9 \%$ in pre-obese subjects, $74.0 \%$ in obese (grade I) patients, and $85.6 \%$ in obese (grade $\geq$ II) patients $(p<0.001)$. A retrospective analysis of a database comprising 1748 patients with surgically treated RCC found significant association between high BMI and low cellular grade [44]. According to authors, the relation between high BMI and renal cancer may explain inverse association between oncological outcomes and obesity. Similar results were obtained in a study of consecutive 1975 patients with metastatic RCC who received targeted therapy (TT) in 19 centres in North America, Europe, and Asia [45]. Albiges et al. [45] observed that obese patients with both metastatic and local disease had better overall survival, after adjustment for International Metastatic Renal Cell Carcinoma Database Consortium (IMDC) prognostic factors. The overall survival of patients with high BMI was 25.6 months (95\% CI: 23.2-28.6 months), while in individuals with low BMI, it was 17.1 months (95\% CI: 15.5-18.5 months). Patients with high BMI also had greater time-to-treatment failure (TTF) in comparison to those with low BMI in first- and second-line therapy. A Cancer Genome Atlas (TCGA)-based analysis of biologic differences associated with different BMI groups failed to find any specific DNA alterations in clear-cell RCC in obese patients [45,46]. However, gene expression profiling revealed marked downregulation of fatty acid synthase (FASN) in obese patients in comparison to normal weight patients. Elevated FASN levels were associated in this study with worse overall survival (median, 15.0 vs. 36.8 months for high FASN and low FASN, respectively; $\log$-rank $p=0.002$ ). This finding is in agreement with the suggestion that the upregulation of FASN is 
a universal phenotypic alteration observed in most human malignancies, which possibly confers a survival growth advantage to tumour cells. The homeostasis of fatty acids (FAs) is controlled by sterol regulatory element-binding proteins (SREBPs) and this process has also been suggested to be essential to support cell survival and tumour growth [47,48]. Albiges et al. [45] suggested a prognostic role of the FA pathway in clear-cell renal cell carcinoma (ccRCC) since they demonstrated that FASN protein was associated with survival and with the IMDC risk groups in patients with metastatic renal cell carcinoma (mRCC) treated with TT. However, it seems that the association between obesity, FASN, and outcome is tumour-specific [45,49]. Renfro et al. [50] have suggested that inverse association between cancer prognosis and obesity, called also "obesity paradox", could be related to a less aggressive disease subtype in obese patients. Accelerated tumour development or its higher aggressiveness may stem from dysregulation of multiple pathways, e.g., the upregulation of oestrogen and insulin levels and other growth factors secreted from adipose tissue, abnormal cholesterol metabolism, and immune system disturbances [51]. Some studies suggested that visceral adipose tissue seemed to be more harmful to health than subcutaneous adipose tissue. However, it appears that in patients with advanced RCC receiving first-line targeted therapy (i.e., sunitinib), visceral adipose tissue may play protective role. In turn, Steffens et al. [52] demonstrated that larger visceral fat area (VFA) and subcutaneous fat area (SFA) were significantly associated with better prognosis and predicted longer progression-free survival (PFS) and overall survival (OS) times. The mechanism of opposite effects of obesity on RCC risk and its prognosis has not been fully unravelled.

Obesity is the more important risk factor associated with insulin resistance and the development of diabetes mellitus type 2 (DM2T) since the adipocytes in visceral tissue secrete substances responsible for insulin resistance, e.g., free fatty acids [8].

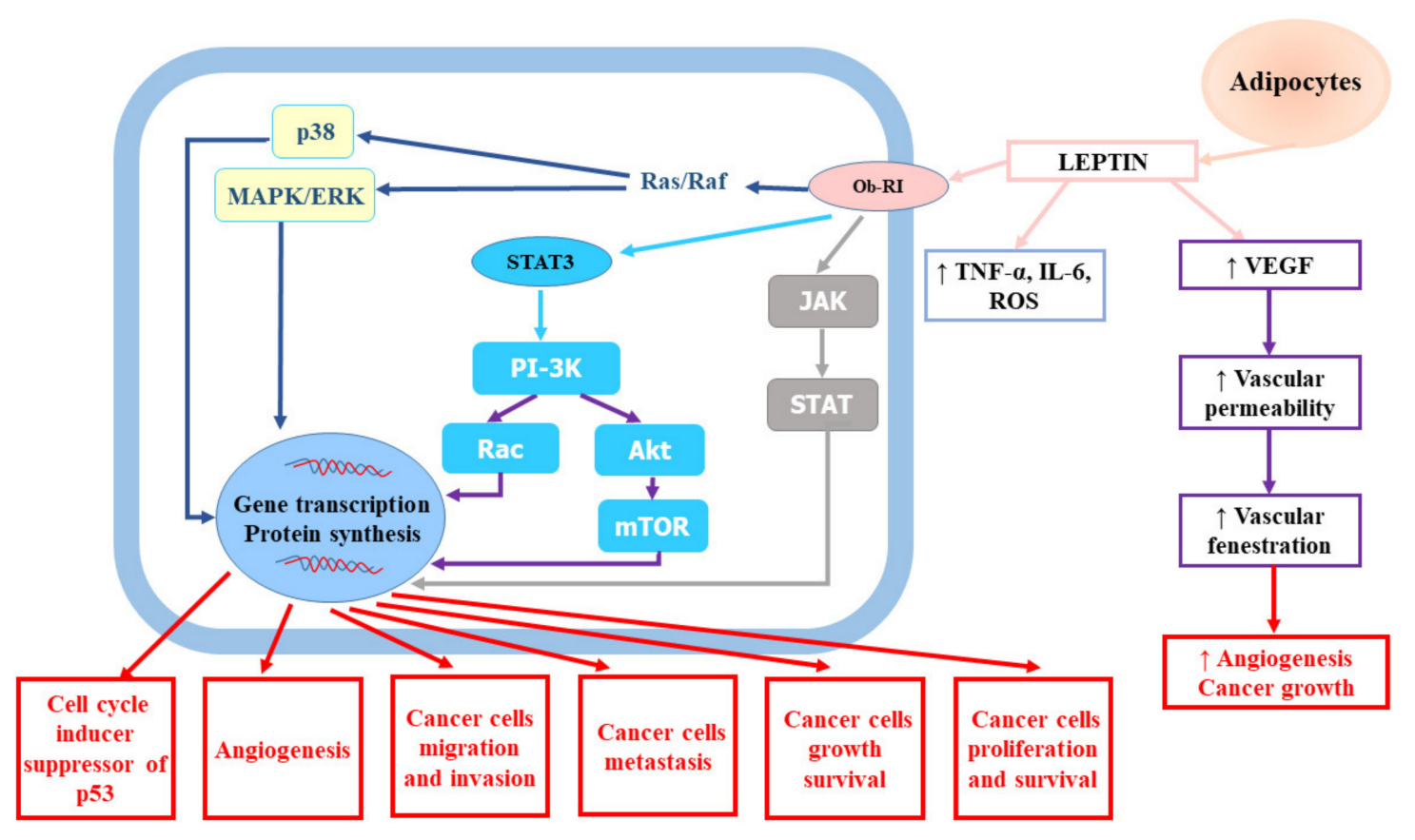

Figure 1. The role of leptin in renal cell cancer development and progression. Akt, protein kinase B; IL-6, interleukin-6; JAK, Janus kinase; MAPK/ERK, mitogen-activated protein kinase/extracellularsignal-regulated kinase; mTOR, mammalian target of rapamycin; Ob-RI, leptin or obesity receptor; PI-3K, phosphatidyl inositol 3-kinase; ROS, reactive oxygen species; STAT3, signal transducer and activator of transcription 3 ; TNF- $\alpha$, tumour necrosis factor- $\alpha$; VEGF, vascular endothelial growth factor. 


\section{Insulin Resistance}

Interactions between insulin and the IGF system appear to be of key importance in the development and progression of RCC [53]; however, the exact role of insulin and IGFs in RCC pathophysiology remains elusive. Gatica et al. [54] demonstrated significantly decreased expression of insulin receptor in patients with DM2T, insulin-resistance, and diabetic nephropathy. Insulin regulates carbohydrate and fat metabolism [55]. High serum levels of insulin have been shown to impede autophagocytosis, proteasome activity, and apoptosis, exerting anti-apoptotic and mitogenic effects [55,56]. In turn, insulin-like growth factors regulate cell growth and proliferation. The IGF family comprises IGF-1, IGF-2, their receptors (IGF-1R and IGF-2R), and six types of IGF-binding proteins (IGFBPs) [1]. The binding of ligands with IGF-1R results in the activation of tyrosine kinase signalling and the phosphorylation of insulin receptor substrate proteins (IRS), which subsequently activate the PI-3K (phosphatidyl inositol 3-kinase)/Akt (protein kinase B)/mTOR (mammalian target of rapamycin) and Ras/MAPK (mitogen-activated protein kinase) pathways [36]. These pathways have been shown to regulate apoptosis and cell proliferation and to be potentially involved in cancer development [57]. IGFs may be involved in the stimulation of mitosis and cell migration, proliferation, differentiation, and hampering of apoptosis as well as malignant transformation [58]. IGF-1 has been shown to stimulate tumour angiogenesis as a result of increasing levels of VEGF [59]. Zhang et al. [60] suggested that the stabilization of hypoxia-inducible factors and inhibition of insulin-like growth factor receptor 1 signalling resulting from von Hippel-Lindau syndrome is the essential mechanism in RCC biology. According to Johansson et al. [61], insulin resistance may lead to compensatory hyperinsulinemia resulting from enhanced insulin secretion by pancreatic $\beta$-cells to maintain normal blood glucose. It has been hypothesized that hyperinsulinemia may augment cancer cell growth and proliferation through insulin action via its receptor and the activation of IGF pathway [62]. Insulin directly and indirectly regulates liver production of IGF-1 through the upregulation of growth hormone (GH) receptors and it also increases IGF-1 bioavailability via the downregulation of IGFBP-1 and IGFBP-2 (which hinders IGF-1 actions) [63]. Suppressed serum IGFBP-1 and increased free IGF-1 have been observed in chronic or short-term hyperinsulinemia [63]. In cancer patients with insulin resistance, the elevated levels of circulating insulin accompanied frequently by insulin receptor (IR) overexpression in cancer cells may be associated with atypical stimulation of non-metabolic effects of IR, including cell proliferation, migration, and survival. Altered splicing of the IR gene resulting in the predominant expression of IR-A (which has enhanced affinity for IGFs, especially for IGF-2) further promotes the aforementioned effects [64].

Takahashi [65] demonstrated that the expression of insulin receptors in RCC tissue of patients who underwent nephrectomy inversely correlated with cancer progression. It was significantly lower in patients with tumour stage pT2-4 and/or distant metastases. Moreover, enhanced IR expression strongly correlated with better disease-free and overall survival after nephrectomy. These findings suggest that hyperinsulinemia does not stimulate RCC progression [65]. Solarek et al. [36] observed downregulated IR expression in RCC cancer cells and they provided evidence that IGF signalling in RCC was predominantly mediated by circulating ligand proteins (IGF-1 and IGF-2) originating from sources other than RCC tumour itself. In turn, Rasmuson et al. [66] failed to find correlation between insulin-like growth factor-1 and IGFBP3 and tumour stage or grade. However, in their study, high serum IGF-1 levels at the time of diagnosis correlated with favourable prognosis; therefore, it seems that serum IGF-1 level may be an independent prognostic factor of renal cell carcinoma. In contrast, Johansson et al. [61] demonstrated significant association between the variables related to fasting insulin and RCC risk. In their Mendelian randomization study, one standard deviation (SD) increment in fasting insulin increased the risk of RCC by $82 \%$. No such relationship was found for type 2 diabetes. It appears that the key mechanism linking diabetes and RCC involves chronic hyperinsulinemia related to pre-diabetic and diabetic status [67]. The impact of hypoglycaemia on prostate cancer development and progression was presented on Figure 2 


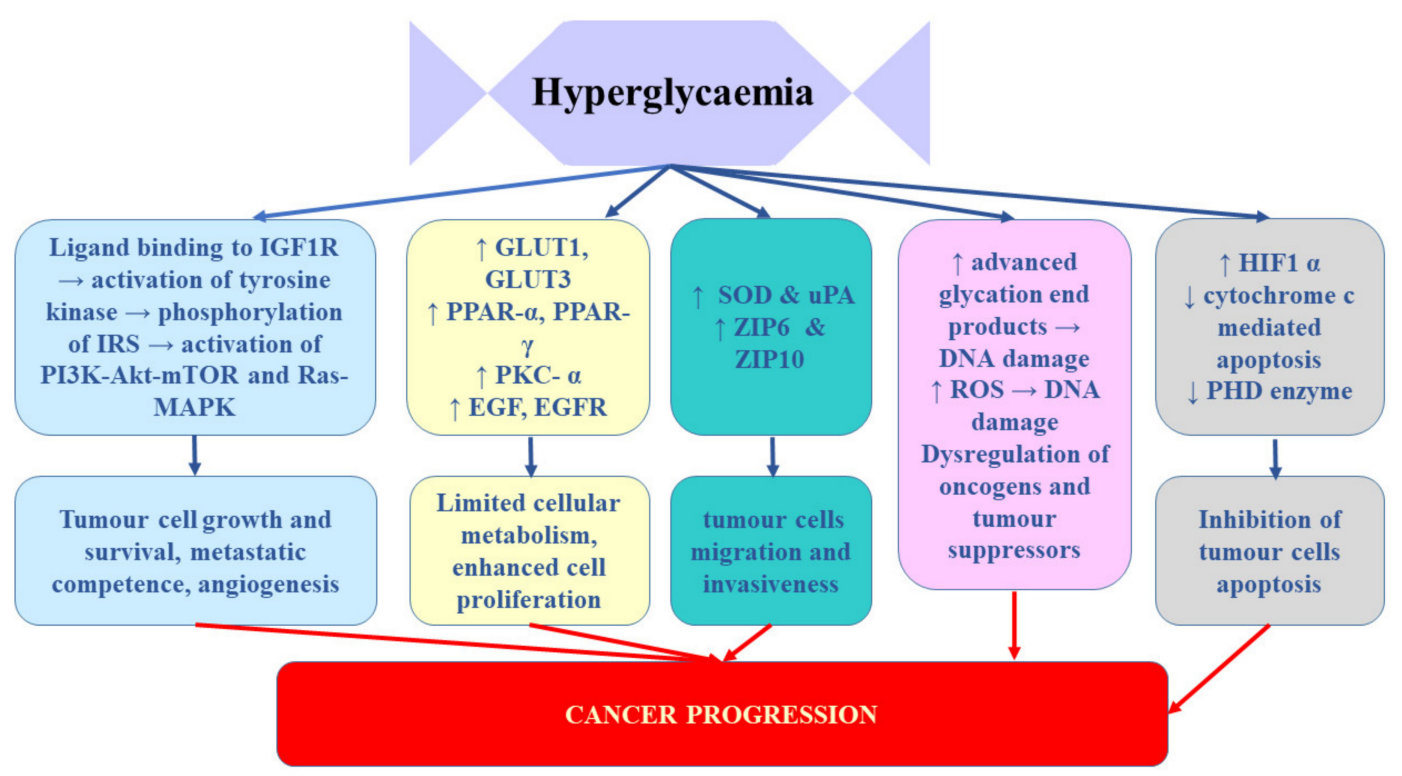

Figure 2. The influence of hypoglycaemia on prostate cancer development and progression. EGF, epidermal growth factor; EGFR, epidermal growth factor receptor; GLUTs, glucose transporters; HIF-1 $\alpha$, hypoxia-inducible factor- $1 \alpha$; IGF-1R, insulin-like growth factor 1 receptor; IRS, insulin receptor substrate; PHD, prolyl hydroxylase domain-containing protein; PKC- $\alpha$, protein kinase C alpha; PPARs, peroxisome proliferator-activated receptors; ROS, reactive oxygen species; $S O D$, superoxide dismutase; uPA, urokinase-type plasminogen activator; ZIP, Zrt-/Irt-like proteins.

\section{Diabetes}

According to studies, the prevalence of RCC in patients with diabetes mellitus ranges from $9.1 \%$ to $25.4 \%$ depending on the studied population, while the incidence of this tumour in general population accounts for approximately $3-5 \%[8,68,69]$. DM is a metabolic disease characterized by chronic hyperglycaemia. The mechanism of DM2T development involves the presence of insulin resistance resulting from the surplus of free fatty acids and the enhanced production of pro-inflammatory cytokines followed by overproduction of insulin by the pancreas as a compensatory mechanism (initially) to insulin resistance and gradual degeneration of pancreatic $\beta$-cells [8]. In the course of insulin resistance, adipocytes may release pro-inflammatory cytokines, which may induce DNA damage resulting finally in carcinogenesis [1]. This thesis was confirmed in a study based on a microarray profile analysis of human kidney from diabetes, renal cell carcinoma, and renal cell carcinoma with diabetes, which revealed numerous DNA modifications in patients from the RCC+diabetes group [70]. In their study, insulin receptor was not only highly expressed, but it also had gains in copy number in patients with diabetes and RCC and in patients with diabetes only. The authors suggested that the analysis of IR copies might be useful as a biomarker allowing the prediction of RCC development in diabetic patients. Since renal cancer is predominantly a metabolic disease, it seems that mutations related to disorders in oxygen, iron, nutrient, and/or energy sensing provide the foundation for the development of cancers and they are indeed frequently observed in renal cancer syndromes [71].

The most commonly mentioned carcinogenic factor observed in the course of diabetes mellitus involves hyperglycaemia, as according to Warburg hypothesis, tumour cells require large amounts of glucose since they use aerobic glycolysis to provide energy and biomolecules regardless of the availability of oxygen [8]. Prolonged hyperglycaemic condition has been observed to result in severe diabetic condition through the damage of pancreatic $\beta$-cells, damage of vascular endothelial cells, and induction of insulin resistance. The resulting $\beta$-cell dysfunction stimulates diminished insulin synthesis and secretion, further aggravating the associated hyperglycaemia. In pathological conditions of hyperinsulinemia, insulin can trigger the proliferation pathway activated by IGF-1 in kidney cancer cells lines. Moreover, IR and IGF-1R were found to promote cellular proliferation and induce metastasis 
in experimental models [72]. Hyperglycaemia was suggested to stimulate cancer cell proliferation by rising the levels of protein kinase C (PKC) and peroxisome proliferator-activated receptors (PPARs), which in turn can hasten cellular metabolism and promote proliferation [73]. Moreover, the presence of DM is associated with the hyperactivation of protein kinase B (Akt)/mTOR regulating most of the cellular pathways, including those involved in renal carcinogenesis. This thesis was supported by a study in which elevated levels of phosphorylated p70S6K (its phosphorylation is caused by activated mTOR kinase) were detected in patients with both DM and RCC and in patients with only DM [74]. Finally, hyperinsulinemia and the insulin-like growth factor family have been suspected to participate in diabetes-related RCC risk. Insulin, as it was described in the previous section, promotes the synthesis and activity of IGF-1 as well as mitosis and cell proliferation and thus, it exerts tumour growth-stimulating effects.

Some studies indicated that the administration of metformin, which is a commonly used anti-diabetic drug, inhibited the growth of renal tumour cells via the stimulation of apoptosis, downregulation of cyclin D1 expression, and G0/G1 cell cycle arrest, as well as reduced cancer mortality in patients with DM2T [75-77]. Moreover, metformin was shown to stimulate AMPK and to inhibit mTOR that plays a role in cell proliferation, differentiation, growth, and survival [76]. If the therapeutic efficiency of metformin is confirmed, it will mean that DM may play an important role in the pathophysiology of RCC [78].

Numerous studies have indicated the relationship between diabetes mellitus and cancers suggesting that some of the DM risk factors can increase an individual's susceptibility to develop a tumour [1]. A large prospective study demonstrated a statistically significant greater risk of developing RCC in diabetic women in comparison to those without type 2 diabetes (multivariable HR $=1.53$; 95\% CI: 1.14-2.04) and this association was independent of obesity, hypertension, and smoking and was the strongest for non-clear-cell RCC [79]. A meta-analysis of 24 studies found considerable relation between diabetes and increased risk of kidney cancer ( $R R=1.40,95 \%$ CI: 1.16-1.69). Again, a slightly stronger positive correlation was observed in women $(\mathrm{RR}=1.47,95 \% \mathrm{CI}: 1.18-1.83)$ than in men $(\mathrm{RR}=1.28,95 \% \mathrm{CI}: 1.10-1.48)$ [80]. The results of these studies may suggest the existence of a different mechanism underlying the impact of type 2 diabetes on RCC risk in women and men, since in the general population, the risk of RCC is greater in men than in women. The impact of female hormones (including oral contraceptives and postmenopausal hormone use) on RCC risk has been analysed; however, the results of studies are conflicting [81,82].

According to Lee et al. [78], diabetes may not significantly affect the aggressiveness and/or progression of RCC. In turn, epidemiological studies imply the relationship between diabetes and enhanced morbidity and mortality of RCC; however, the results of studies are sometimes conflicting. In patients with surgically treated clear-cell renal cell carcinoma, the 5-year overall survival was significantly worse in those with diabetes $(65 \%$ vs. $74 \%, p<0.001)$ [20]. Moreover, a multivariable analysis revealed that diabetes mellitus independently predicted cancer-specific mortality (HR $=1.55$, 95\% CI: 1.08-2.21, $p=0.02$ ) and all-cause mortality (HR $=1.32,95 \%$ CI: 1.06-1.64, $p=0.01$ ).

In contrast, the follow-up of participants from the Nurses' Health Study (NHS) and the Health Professionals Follow-Up Study (HPFS) failed to find the effect of diabetes on the incidence of fatal RCC in both women (HR $=1.35,95 \%$ CI: $0.72-2.55)$ and women (HR $=1.23,95 \%$ CI: 0.54-2.76) [79]. Similarly, a large meta-analysis reported no association between diabetes and mortality of kidney cancer ( $R R=1.12,95 \%$ CI: 0.99-1.20) [80]. In turn, Lee et al. [78] observed significantly lower overall survival, cancer-specific survival (CSS), and non-cancer-related survival in patients with diabetes mellitus and renal cancer in comparison to patients without diabetes. The authors suggested that it was not the presence/absence of diabetes that affected RCC-related outcomes, but the time from diagnosis of DM or degree of long-term glycaemic control. Moreover, they reported that the presence of DM before surgical treatment was a strong predictor of overall survival and non-cancer-specific survival, but not cancer-specific survival in patients with localized clear-cell RCC, following the adjustment for numerous pre-operative variables and known prognostic factors. The impact of DM presence on overall 
and non-cancer-specific survival may be associated with the fact that this disease increases the risk of cardiovascular mortality. Indeed, in the abovementioned study, most of non-RCC-related mortality was due to cerebrovascular and heart-related conditions [78]. In a subsequent study performed by Lee et al. [83], diabetes was an independent predictor of disease progression ( $\mathrm{HR}=1.766, p=0.002)$, cancer-specific mortality ( $\mathrm{HR}=2.266, p=0.001$ ), and all-cause mortality (odds ratio $[\mathrm{OR}]=1.825$, $p=0.001$ ), while elevated pre-operative $\mathrm{HbA} 1 \mathrm{c}$ was shown to predict post-operative disease progression ( $\mathrm{HR}=2.221, p=0.023)$ A long-term retrospective single-centre study demonstrated a higher risk of all-cause mortality in patients with RCC and pre-existing DM2T at the time of diagnosis compared to individuals without diabetes [84]. However, they noticed the impact of DM on cancer-specific survival; the estimated CSS rates in patients with DM2T vs. non-DM2T were as follows: at 1 year, $63.4 \%$ vs. $76.7 \%$; at 3 years, $30.4 \%$ vs. $56.6 \%$; and at 5 years, $16.3 \%$ vs. $48.6 \%$ ( $p=0.001$ ). Moreover, Yuk et al. [12] found significantly shorter progression-free, cancer-specific, and overall survival of patients with pre-operative diabetes mellitus than non-DM ones (all $p<0.05$ ), as well as worse oncological outcomes in diabetic individuals with poor glycaemic control compared to those with good glycaemic control. Finally, Fukushima et al. [85] reported the relationship between DM and the rate of recurrences following surgery for non-metastatic renal cell carcinoma ( $\mathrm{HR}=2.43, p=0.003)$, especially in obese patients ( $\mathrm{HR}=4.07, p=0.010)$. Obesity altered the impact of diabetes mellitus on recurrence with a trend $(p$-interaction $=0.086)$. The 5 -year recurrence-free survival rate in obese patients with DM was $75.3 \%$, while in obese patients without DM, it was $91.9 \%(p<0.001)$. Figure 3 presents pathomechanisms related to cancer development and progression in diabetes mellitus.

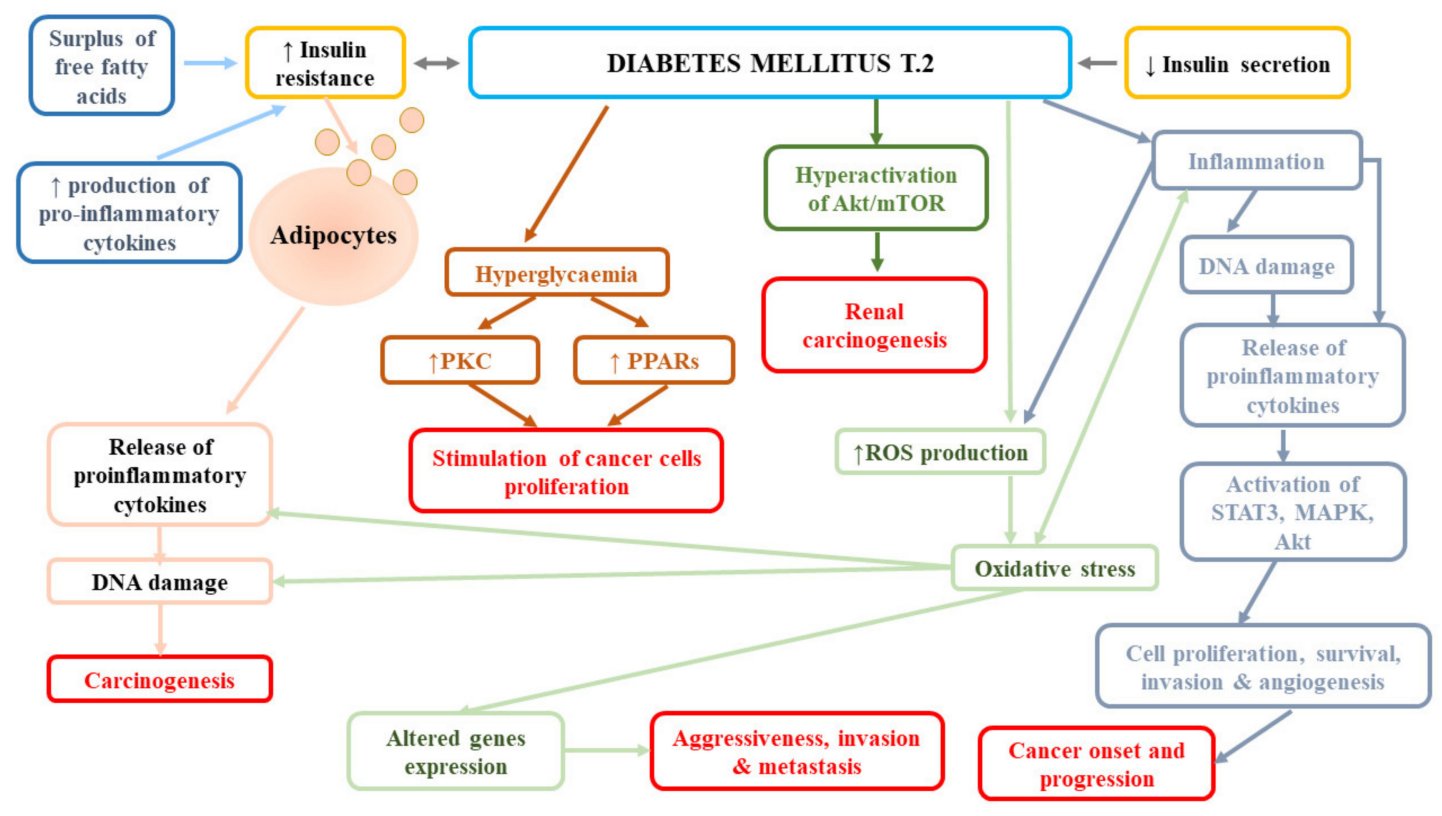

Figure 3. Pathomechanisms related to cancer development and progression in diabetes mellitus. Akt, protein kinase B; MAPK, mitogen-activated protein kinase; PKC, protein kinase C; PPARs, peroxisome proliferator-activated receptors; ROS, reactive oxygen species; STAT3, signal transducer and activator of transcription 3.

\section{Dyslipidemia}

Lipid disorders have been suggested to be involved in the pathomechanisms of various cancers, including oesophageal, colon, rectal, and renal cancers [86,87]. According to numerous studies, clear-cell renal cancer is also characterized by sterol storage in tumour cells resulting in alterations in lipid metabolism and consequently, in the formation and progression of RCC $[1,88]$. However, the exact mechanisms are not fully understood as the results of studies are sometimes conflicting. Some studies have demonstrated decreased cancer incidence and mortality in patients with high baseline levels of 
total cholesterol (TC), while other have indicated an inverse relationship or the existence of a U-shaped association with TC levels [89-94].

A prospective cohort study (Swedish AMORIS study) demonstrated a consistent relation only between triglyceride (TG) levels and kidney cancer risk [18]. A 1:2-matched case-control study, in which renal cell carcinoma patients were matched (in terms of age and gender) to doubled number of non-renal-cell-carcinoma residents, found a relationship between low high-density lipoprotein (HDL) levels and greater risk of renal cell carcinoma (HR $=1.646,95 \%$ CI: 1.187-2.282) as well as between high levels of TC ( $\mathrm{HR}=0.537,95 \% \mathrm{CI}$ : $0.374-0.772)$ and high concentration of low-density lipoprotein (LDL) (HR $=0.649,95 \%$ CI: 0.442-0.971) and diminished risk of renal cell carcinoma, after adjusting for obesity, smoking, hypertension, and diabetes [95]. The increase in low-density lipoprotein cholesterol (LDL-C) level by $1 \mathrm{mmol} / \mathrm{L}$ was associated with $25.5 \%$ reduction in renal cell cancer hazard. On the basis of obtained results, Zhang et al. [95] suggested that the impact of HDL on carcinogenesis might involve its effects on cytokine production, anti-oxidative properties, the regulation of cell cycle entry via a mitogen activated protein kinase-dependent pathway, and apoptosis, but it was also plausible that other factors affected both HDL cholesterol levels and the risk of cancer development [96-98]. Similarly, a Mendelian randomization study including participants from the Copenhagen City Heart Study (CCHS) and Copenhagen General Population Study revealed that low plasma levels of LDL cholesterol $(<87 \mathrm{mg} / \mathrm{dL}$ ) were strongly associated with $43 \%$ increased risk of cancer (including kidney cancer) in comparison to individuals with LDL $>158 \mathrm{mg} / \mathrm{dL}$ (95\% CI: $15 \%-79 \%$ increase) [99]. Their finding did not apply to patients with genetically reduced LDL cholesterol levels, which implies that low LDL cholesterol levels per se do not cause cancer. In contrast, a retrospective case-control study of patients with newly diagnosed sporadic RCC [88] reported an upward trend for the occurrence of advanced RCC with rising serum LDL levels. Elevated levels of LDL also frequently co-existed with the presence of clear-cell RCC. In turn, Ahn et al. [100] demonstrated a marginally significant association between high serum concentrations of total cholesterol and a reduced risk of kidney cancer. Another European cohort study reported the relationship between triglyceride and RCC hazard only in men, but not in women [10]. In a retrospective study investigating the association between metabolic factors and the histopathological characteristics of renal cell carcinoma, patients in the high-grade group were observed to have lower HDL cholesterol in comparison to the low-grade group $(p=0.015)$ [101]. Lower HDL cholesterol and total cholesterol level were found in those with more advanced cancer than those with localized disease ( $p=0.006$ and $p=0.005$, respectively). Lower concentrations of LDL cholesterol correlated with the presence of larger tumours $(p=0.030)$. Finally, logistic analyses performed in this study indicated associations between total cholesterol and tumour stage (OR $=0.660,95 \% \mathrm{CI}$ : $0.492-0.884, p=0.005)$, HDL cholesterol level and tumour grade (OR $=0.293,95 \% \mathrm{CI}$ : $0.108-0.797$, $p=0.016$ ), and stage (OR $=0.204,95 \%$ CI: $0.065-0.635, p=0.006)$, as well as LDL levels and tumour diameter (OR $=0.756,95 \% \mathrm{CI}: 0.586-0.975, p=0.031)$ [101].

Some studies indicated that the administration of statins (inhibitors of 3-hydroxy-3-methylglutaryl coenzyme A reductase) used in the treatment of lipid disorders seemed to exert protective effects against the development of RCC [1,102]. Horiguchi et al. [102] in their in vitro experimental model assessed the therapeutic efficacy of fluvastatin against renal cancer growth, invasion, angiogenesis, and pulmonary metastasis. They observed that fluvastatin even at relatively low concentrations $(0.1$ and $1 \mu \mathrm{mol} / \mathrm{L})$ diminished Renca cell proliferation, with up to $70 \%$ inhibition at $10 \mu \mathrm{mol} / \mathrm{L}$. The observed inhibitory effect was suggested to be related to the induction of apoptosis. Doses of fluvastatin recommended for the treatment of hypercholesterolemia were also shown to exert an antiproliferative effect by blocking the transition of G1-S in the cell cycle as a result of the increase in p21WAF/CIP1 (cyclin-dependent kinase inhibitor) and to significantly hamper renal cancer cell invasion and angiogenesis, resulting in reduced pulmonary metastasis [102]. Since the treatment with oral fluvastatin is well-tolerated and cost-effective, it seems that it could be used as an effective treatment for preventing the invasion and pulmonary metastasis of renal cancer cells. Figure 4 summarizes the protective role of HDL in cancer development. 


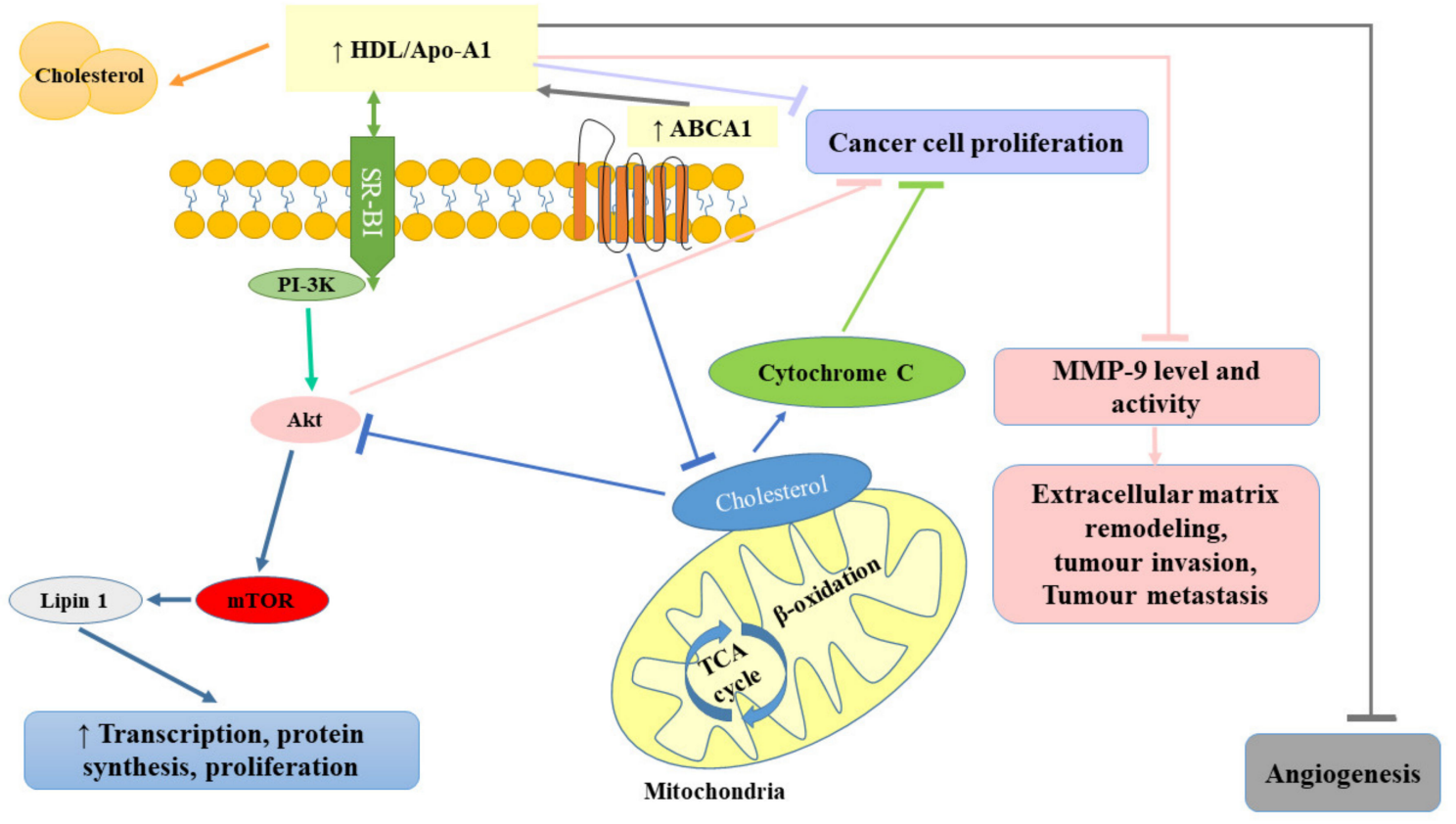

Figure 4. Protective role of high-density lipoprotein (HDL) in cancer development. ABCA1, ATP-binding cassette transporter; Akt, protein kinase B; Apo-A1, apolipoprotein A-I; HDL, high-density lipoprotein; MMP-9, matrix metallopeptidase-9; mTOR, mammalian target of rapamycin; PI-3K, phosphatidyl inositol 3-kinase; SR-BI, scavenger receptor class B type 1; TCA, trichloroacetic acid.

Table 1 presents the summary of most important studies included in this review.

Table 1. The summary of most important studies included in this review.

\begin{tabular}{|c|c|c|c|c|}
\hline Factor & Type of Study & Study Group & Most Important Results & Reference \\
\hline \multirow{3}{*}{$\begin{array}{l}\text { Obesity, leptin, and } \\
\text { adiponectin levels }\end{array}$} & $\begin{array}{c}\text { Quantitative } \\
\text { summary analysis }\end{array}$ & $\begin{array}{l}14 \text { studies on men } \\
\text { and women }\end{array}$ & $\begin{array}{l}\text { Summary relative risk estimate was } 1.07(95 \% \\
\text { confidence interval (CI): 1.05-1.09) per unit of } \\
\text { increase in body mass index (BMI) corresponding } \\
\text { to } 3 \mathrm{~kg} \text { body weight increase for a subject of } \\
\text { average height). } \\
\text { No evidence of effect modification by sex. } \\
\text { Conclusion: Increased BMI is equally strongly } \\
\text { associated with an increased risk of renal cell cancer } \\
\text { among men and women. }\end{array}$ & [22] \\
\hline & $\begin{array}{l}\text { Meta-analysis in } \\
\text { accordance with } \\
\text { PRISMA guideline }\end{array}$ & $\begin{array}{c}24 \text { cohort studies } \\
\text { with } 8,953,478 \\
\text { participants }\end{array}$ & $\begin{array}{l}\text { Pooled relative risk (RR) of kidney cancer was } 1.35 \\
(1.27-1.43) \text { in overweight and } 1.76(1.61-1.91) \text { in } \\
\text { obese participants compared to those with } \\
\text { normal weight. } \\
\text { Increased kidney cancer risk of } 1.06(1.05-1.06) \text { for } \\
\text { each } 1 \mathrm{~kg} / \mathrm{m}^{2} \text { increase in BMI (risk increased by } 6 \% \\
\text { in men }(\mathrm{RR}=1.06,95 \% \mathrm{CI}: 1.05-1.08) \text { in men and } \\
5 \% \text { in women (RR }=1.05,95 \% \text { CI: } 1.04-1.06) . \\
\text { Conclusion: The overall and dose-response } \\
\text { meta-analysis suggested that overweight/obesity } \\
\text { increases the risk of kidney cancer both in men } \\
\text { and women. }\end{array}$ & {$[23]$} \\
\hline & $\begin{array}{c}\text { Nationwide, } \\
\text { population-based } \\
\text { cohort study, also } \\
\text { based on Israel } \\
\text { National Cancer } \\
\text { Registry }\end{array}$ & $\begin{array}{l}1,110,835 \text { males, } \\
\text { aged } 16-19 \text { years, } \\
\text { examined for } \\
\text { fitness for military } \\
\text { service; } 274 \text { of them } \\
\text { developed renal } \\
\text { cancer }\end{array}$ & $\begin{array}{l}\text { Substantial excess risk related to body mass index } \\
\text { of greater than } 27.5 \mathrm{~kg} / \mathrm{m}^{2} \text { compared with less than } \\
22.5 \mathrm{~kg} / \mathrm{m}^{2} \text { (hazard ratio }(\mathrm{HR})=2.43,95 \% \mathrm{CI} \text { : } \\
1.54-3.83, p<0.0001 \text { ). } \\
\text { Asian or African origin was protective compared } \\
\text { with European origin (African origin: HR }=0.67 \text {, } \\
95 \% \text { CI: } 0.49-0.92 \text { ). } \\
\text { Conclusion: Overweight in late adolescence is a } \\
\text { substantial risk factor for renal cell carcinoma. European } \\
\text { origin is independently associated with excess risk. }\end{array}$ & [24] \\
\hline
\end{tabular}


Table 1. Cont.

\begin{tabular}{|c|c|c|c|c|}
\hline Factor & Type of Study & Study Group & Most Important Results & Reference \\
\hline & Case-control study & $\begin{array}{l}70 \text { patients with } \\
\text { histologically } \\
\text { confirmed renal } \\
\text { cell carcinoma } \\
\text { (RCC) and } 280 \\
\text { healthy controls } \\
\text { matched by gender, } \\
\text { age, and county of } \\
\text { residence }\end{array}$ & $\begin{array}{l}\text { Serum adiponectin levels were statistically, } \\
\text { significantly, and inversely associated with RCC } \\
\text { when compared with controls (odds ration [OR] = } \\
0.76, p=0.05 \text { ). } \\
\text { Conclusion: Low adiponectin levels are significantly } \\
\text { associated with RCC and may mediate the effect of } \\
\text { central or visceral adiposity on the pathogenesis of RCC. }\end{array}$ & [29] \\
\hline & Case-control study & $\begin{array}{l}\text { Caucasians (581 } \\
\text { cases, } 558 \text { controls) } \\
\text { and African } \\
\text { Americans ( } 187 \\
\text { cases, } 359 \text { controls) }\end{array}$ & $\begin{array}{l}\text { In Caucasians, the ORs for RCC comparing the } \\
\text { highest (Q4) to the lowest (Q1) sex-specific quartile } \\
\text { of leptin were } 3.2 \text { ( } 95 \% \text { CI: } 1.9-5.2) \text { for males and } \\
4.7(95 \% \text { CI: } 2.6-8.6) \text { for females. } \\
\text { Serum leptin was not significantly associated with } \\
\text { RCC among African American males or females. } \\
\text { Higher adiponectin was associated with RCC risk } \\
\text { among African American males (Q4 vs. Q1: OR = } \\
\text { 2.3, 95\% CI: 1.1-4.6) and females (OR = 2.1, 95\% CI: } \\
\text { 1.2-6.7). } \\
\text { Adiponectin was not significantly associated with } \\
\text { RCC risk among Caucasian males and females. } \\
\text { Conclusion: Leptin and adiponectin concentrations are } \\
\text { associated with the risk of RCC, which may differ by } \\
\text { race. }\end{array}$ & [31] \\
\hline & Case-control study & $\begin{array}{l}1338 \text { clear-cell RCC } \\
\text { patients with } \\
\text { complete } \\
\text { information about } \\
\text { their BMI }\end{array}$ & $\begin{array}{l}\text { Lower BMI was significantly associated with } \\
\text { higher age, tumour grade, and the rate of } \\
\text { metastasis at diagnosis. } \\
\text { Significantly lower risk of cancer-related death in } \\
\text { overweight patients (median 5-year } \\
\text { tumour-specific survival rate: } 70.9 \% \text { (pre-obese), } \\
74.0 \% \text { (obese grade I), and } 85.6 \% \text { (obese grade } \geq \text { II) } \\
\text { compared with } 63.8 \% \text { for patients with BMI below } \\
25(p<0.001 \text { ). } \\
\text { Overweight is an independent prognostic marker } \\
\text { of improved cancer-specific survival in patients } \\
\text { with organ-confined, but not advanced, RCC. }\end{array}$ & [43] \\
\hline & $\begin{array}{l}\text { International, } \\
\text { multi-institutional } \\
\text { retrospective } \\
\text { review }\end{array}$ & $\begin{array}{l}1748 \text { patients with } \\
\text { median BMI of } 28 \\
\text { who underwent } \\
\text { surgery for } \\
\text { clinically localized } \\
\text { renal masses }\end{array}$ & $\begin{array}{l}\text { Increased distribution of low-grade RCC with } \\
\text { increasing BMI ( } p<0.05 \text { ). } \\
\text { In a multivariable model (including age, sex, and } \\
\text { tumour size), higher BMI groups had lower odds } \\
\text { of presenting a high Fuhrman grade. } \\
\text { Conclusions: Higher BMI is associated with a lower } \\
\text { grade of RCC in clinically localized renal masses. }\end{array}$ & [44] \\
\hline & Case-control study & $\begin{array}{l}1975 \text { patients from } \\
\text { the International } \\
\text { Metastatic Renal } \\
\text { Cell Carcinoma } \\
\text { Database } \\
\text { Consortium } \\
\text { (IMDC), external } \\
\text { validation cohort of } \\
4657 \text { patients. }\end{array}$ & $\begin{array}{l}\text { High BMI was associated with improved overall } \\
\text { survival (OS; adjusted hazard ratio = } 0.83,95 \% \text { CI: } \\
0.74-0.93 \text { ). } \\
\text { Fatty acid synthase (FASN) immunohistochemistry } \\
\text { positivity was more frequently detected in IMDC } \\
\text { poor ( } 48 \% \text { ) and intermediate ( } 34 \% \text { ) risk groups } \\
\text { than in the favourable risk group (17\%; } p \text {-trend = } \\
0.015) \text {. } \\
\text { FASN protein levels were associated with survival } \\
\text { in patients with metastatic RCC (mRCC). } \\
\text { Conclusions: High BMI is a prognostic factor for } \\
\text { improved survival and progression-free survival in } \\
\text { patients with metastatic RCC treated with targeted } \\
\text { therapy. FASN pathway is involved in RCC risk. }\end{array}$ & [45] \\
\hline & Case-control study & $\begin{array}{l}116 \text { patients with } \\
\text { metastatic RCC } \\
\text { receiving } \\
\text { anti-angiogenic } \\
\text { agents (sunitinib, } \\
\text { sorafenib, axitinib, } \\
\text { bevacizumab) }\end{array}$ & $\begin{array}{l}\text { Conclusions: Higher than average visceral fat area } \\
\text { (VFA) and subcutaneous fat area (SFA) levels were } \\
\text { significant predictors of longer progression-free and } \\
\text { overall survival times. }\end{array}$ & [52] \\
\hline
\end{tabular}


Table 1. Cont.

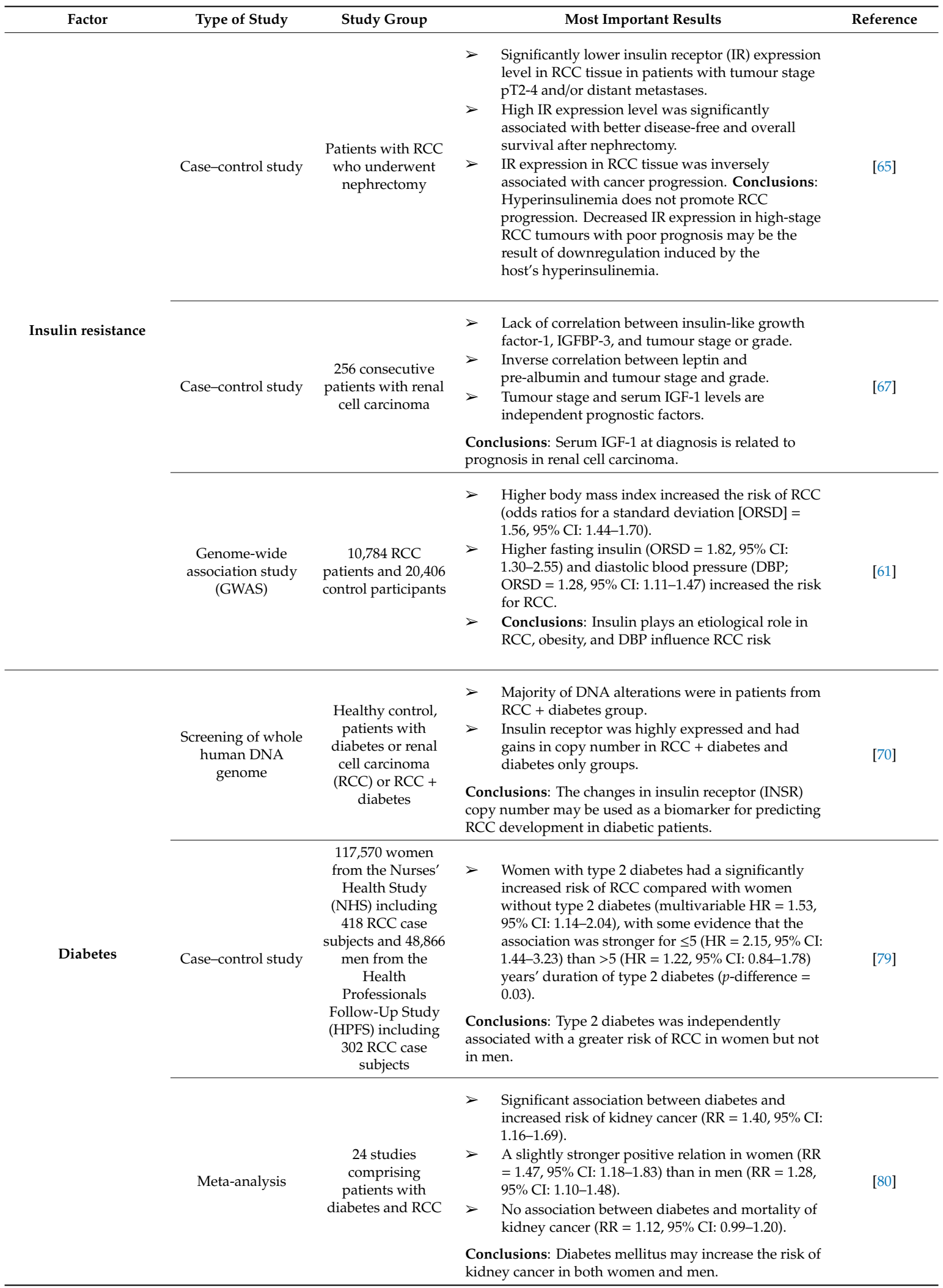


Table 1. Cont.

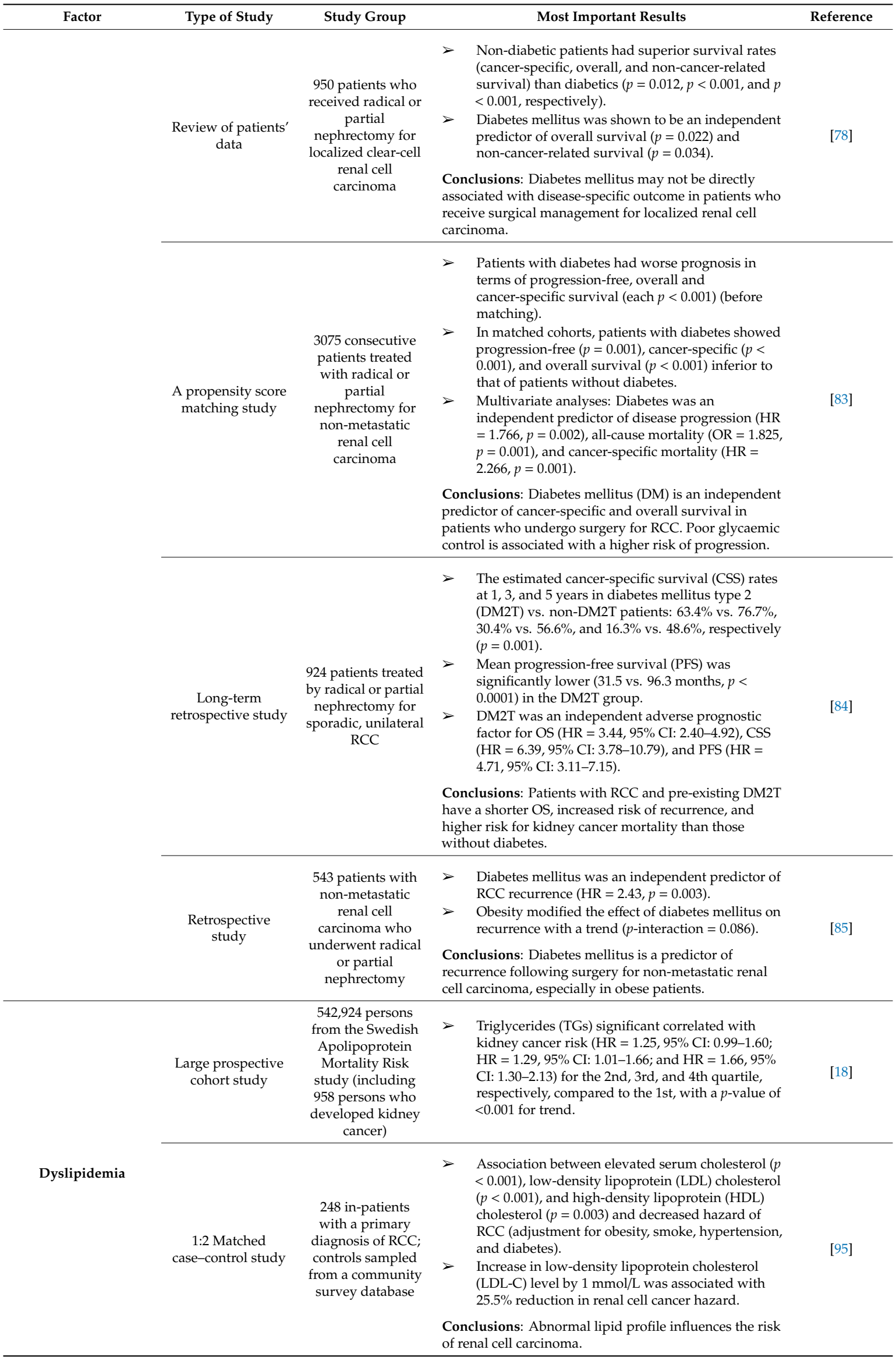


Table 1. Cont.

\begin{tabular}{|c|c|c|c|c|}
\hline Factor & Type of Study & Study Group & Most Important Results & Reference \\
\hline & $\begin{array}{c}\text { Mendelian } \\
\text { randomization } \\
\text { study }\end{array}$ & $\begin{array}{l}10,613 \text { participants } \\
\text { in the Copenhagen } \\
\text { City Heart Study } \\
\text { (CCHS) and } 59,566 \\
\text { participants in the } \\
\text { Copenhagen } \\
\text { General Population } \\
\text { Study, } 6816 \text { of } \\
\text { whom had } \\
\text { developed cancer }\end{array}$ & $\begin{array}{l}\text { LDL }<87 \mathrm{mg} / \mathrm{dL} \text { was associated with a } 43 \% \\
\text { increase ( } 95 \% \text { CI: } 15 \%-79 \% \text { increase) in the risk } \\
\text { of cancer. } \\
\text { The polymorphisms were associated with up to a } \\
38 \% \text { reduction ( } 95 \% \text { CI: } 36 \%-41 \% \text { reduction) in } \\
\text { LDL cholesterol levels, but not with increased risk } \\
\text { of cancer. } \\
\text { Conclusions: Low plasma LDL cholesterol levels were } \\
\text { robustly associated with an increased risk of cancer, but } \\
\text { genetically decreased LDL cholesterol was not. This } \\
\text { finding suggests that low LDL cholesterol levels per se } \\
\text { do not cause cancer. }\end{array}$ & [99] \\
\hline & $\begin{array}{l}\text { Retrospective } \\
\text { study }\end{array}$ & $\begin{array}{l}382 \text { consecutive } \\
\text { RCC patients who } \\
\text { underwent radical } \\
\text { or partial } \\
\text { nephrectomy }\end{array}$ & $\begin{array}{l}\text { Patients in the high-grade cancer group had lower } \\
\text { HDL-cholesterol level than those in the low-grade } \\
\text { group }(p=0.015) \text {. } \\
\text { Total cholesterol levels were lower in advanced } \\
\text { disease than in localized disease }(p=0.005) . \\
\text { LDL-cholesterol was lower in larger tumours }(p= \\
0.030) \text {. } \\
\text { Conclusions: Metabolic factors, especially obesity and } \\
\text { serum lipid profile, are closely related with the } \\
\text { histopathological characteristics of renal cell carcinoma. }\end{array}$ & [88] \\
\hline
\end{tabular}

It is worth mentioning that cancer may cause protein-energy wasting syndrome, which affects metabolic factors evaluated in this review; therefore, some of the disturbances described here could be related to the disease. Metabolic impairment contributes to the clinical deterioration seen in advanced cancer patients, including weight loss, skeletal muscle wasting, as well as the atrophy of the adipose tissue [103]. Cancer-associated cachexia (CAC) progresses rapidly resulting in irreversible deterioration of health and survival; however, its appearance seems to be mostly unpredictable and the severity of CAC is frequently not related to tumour size or stage. Metabolic dysfunction in cancer results from the deregulation of carbohydrate and lipid metabolism. Tumour tissue takes up glucose, therefore the decreased levels of glucose observed in such patients can be ascribed to cancer development. Reduced glucose tolerance observed in cancer patients could be ascribed to enhanced hepatic glucose production or its diminished peripheral utilization [103]. Moreover, in severely sick patients with cancers, a paradoxical rise in serum lipid levels was observed despite the loss of body weight. According to some studies, hypertriglyceridemia could be the result of the inhibition of lipoprotein lipase (LPL) [104].

\section{Conclusions}

The results or numerous studies suggests that metabolic factors, especially diabetes mellitus, obesity, and serum lipid profile, are closely associated with the risk of renal cell carcinoma, as well as its histopathological characteristics and survival. Worse outcomes seem to be the result of the presence of metabolic factors per se. It appears that obesity increases the risk of RCC development; however, it may also be a favourable factor in terms of prognosis. Obesity is closely related to insulin resistance and the development of diabetes mellitus type 2 since the adipocytes in visceral tissue secrete substances responsible for insulin resistance, e.g., free fatty acids. Interactions between insulin and the IGF system appear to be of key importance in the development and progression of RCC; however, the exact role of insulin and IGFs in RCC pathophysiology remains elusive. Studies indicated that diabetes increased the risk of RCC, but it might not alter cancer-related survival. The risk associated with lipid profile is most mysterious, as numerous studies provided conflicting results. Despite the fact that large studies unravelling pathomechanisms involved in cancer growth are required to finally establish the impact of metabolic factors on the development, progression, and prognosis of renal cancers, it seems that the monitoring of health conditions, such as diabetes, low BMI, and lipid disorders is of high importance in clear-cell type RCC. There are still numerous questions awaiting clarification. 
More and more sophisticated techniques of molecular biology should enable the identification of key metabolic enzymes and pathways involved in cancer development and progression. Metabolic profiling of samples from cancer and non-cancer patients could provide relevant information on whether there exists a specific, characteristic metabolic profile of tumour cells that is different from that of non-transformed proliferating cells. Perhaps future studies will provide the information if metabolic particularities of cancer cells can be exploited without affecting normal tissues. Moreover, it is of interest how the diet or DM treatment influences cancer development and therapy.

Author Contributions: All authors were involved in the preparation of this article and J.R. revised the final version. All authors have read and agreed to the published version of the manuscript.

Funding: This research received no external funding

Conflicts of Interest: The authors declare no conflict of interest.

\section{References}

1. Zhang, G.M.; Zhu, Y.; Ye, D.W. Metabolic syndrome and renal cell carcinoma. World J. Surg. Oncol. 2014, 12, 236. [CrossRef] [PubMed]

2. Wu, Q.; Chen, G.; Wu, W.M.; Zhou, L.; You, L.; Zhang, T.P.; Zhao, Y.P. Metabolic syndrome components and risk factors for pancreatic adenocarcinoma: A case-control study in China. Digestion 2012, 86, 294-301. [CrossRef] [PubMed]

3. Forootan, M.; Tabatabaeefar, M.; Yahyaei, M.; Maghsoodi, N. Metabolic syndrome and colorectal cancer: A cross-sectional survey. Asian Pac. J. Cancer Prev. 2012, 13, 4999-5002. [CrossRef] [PubMed]

4. Haggstrom, C.; Stocks, T.; Rapp, K.; Bjorge, T.; Lindkvist, B.; Concin, H.; Engeland, A.; Manjer, J.; Ulmer, H.; Selmer, R.; et al. Metabolic syndrome and risk of bladder cancer: Prospective cohort study in the metabolic syndrome and cancer project (Me-Can). Int. J. Cancer 2011, 128, 1890-1898. [CrossRef]

5. Penaranda, E.K.; Shokar, N.; Ortiz, M. Relationship between Metabolic Syndrome and History of Cervical Cancer among a US National Population. ISRN Oncol. 2013, 2013, 840964. [CrossRef]

6. Hammarsten, J.; Peeker, R. Urological aspects of the metabolic syndrome. Nat. Rev. Urol. 2011, 8, 483-494. [CrossRef]

7. Buschemeyer, W.C., 3rd; Freedland, S.J. Obesity and prostate cancer: Epidemiology and clinical implications. Eur. Urol. 2007, 52, 331-343. [CrossRef]

8. Labochka, D.; Moszczuk, B.; Kukwa, W.; Szczylik, C.; Czarnecka, A.M. Mechanisms through which diabetes mellitus influences renal cell carcinoma development and treatment: A review of the literature. Int. J. Mol. Med. 2016, 38, 1887-1894. [CrossRef]

9. Znaor, A.; Lortet-Tieulent, J.; Laversanne, M.; Jemal, A.; Bray, F. International variations and trends in renal cell carcinoma incidence and mortality. Eur. Urol. 2015, 67, 519-530. [CrossRef]

10. Haggstrom, C.; Rapp, K.; Stocks, T.; Manjer, J.; Bjorge, T.; Ulmer, H.; Engeland, A.; Almqvist, M.; Concin, H.; Selmer, R.; et al. Metabolic factors associated with risk of renal cell carcinoma. PLoS ONE 2013, 8, e57475. [CrossRef]

11. King, S.C.; Pollack, L.A.; Li, J.; King, J.B.; Master, V.A. Continued increase in incidence of renal cell carcinoma, especially in young patients and high grade disease: United States 2001 to 2010. J. Urol. 2014, 191, 1665-1670. [CrossRef] [PubMed]

12. Yuk, H.D.; Hwang, E.C.; Park, J.Y.; Jeong, C.W.; Song, C.; Seo, S.I.; Byun, S.S.; Kwak, C.; Hong, S.H.; Kang, M.; et al. The number of metabolic features as a significant prognostic factor in patients with metastatic renal cell carcinoma. Sci. Rep. 2020, 10, 6967. [CrossRef] [PubMed]

13. Hoerner, C.R.; Chen, V.J.; Fan, A.C. The 'Achilles Heel' of Metabolism in Renal Cell Carcinoma: Glutaminase Inhibition as a Rational Treatment Strategy. Kidney Cancer 2019, 3, 15-29. [CrossRef] [PubMed]

14. Chow, W.H.; Dong, L.M.; Devesa, S.S. Epidemiology and risk factors for kidney cancer. Nat. Rev. Urol. 2010, 7, 245-257. [CrossRef] [PubMed]

15. Chow, W.H.; Devesa, S.S.; Warren, J.L.; Fraumeni, J.F., Jr. Rising incidence of renal cell cancer in the United States. JAMA 1999, 281, 1628-1631. [CrossRef] [PubMed]

16. Joh, H.K.; Willett, W.C.; Cho, E. Type 2 diabetes and the risk of renal cell cancer in women. Diabetes Care 2011, 34, 1552-1556. [CrossRef] 
17. Chow, W.H.; Gridley, G.; Fraumeni, J.F., Jr.; Jarvholm, B. Obesity, hypertension, and the risk of kidney cancer in men. N. Engl. J. Med. 2000, 343, 1305-1311. [CrossRef]

18. Van Hemelrijck, M.; Garmo, H.; Hammar, N.; Jungner, I.; Walldius, G.; Lambe, M.; Holmberg, L. The interplay between lipid profiles, glucose, BMI and risk of kidney cancer in the Swedish AMORIS study. Int. J. Cancer 2012, 130, 2118-2128. [CrossRef]

19. Hu, J.; Mao, Y.; White, K.; Canadian Cancer Registries Epidemiology Research Group. Overweight and obesity in adults and risk of renal cell carcinoma in Canada. Soz Prav. 2003, 48, 178-185. [CrossRef]

20. Psutka, S.P.; Stewart, S.B.; Boorjian, S.A.; Lohse, C.M.; Tollefson, M.K.; Cheville, J.C.; Leibovich, B.C.; Thompson, R.H. Diabetes mellitus is independently associated with an increased risk of mortality in patients with clear cell renal cell carcinoma. J. Urol. 2014, 192, 1620-1627. [CrossRef]

21. Rini, B.I.; Cohen, D.P.; Lu, D.R.; Chen, I.; Hariharan, S.; Gore, M.E.; Figlin, R.A.; Baum, M.S.; Motzer, R.J. Hypertension as a biomarker of efficacy in patients with metastatic renal cell carcinoma treated with sunitinib. J. Natl. Cancer Inst. 2011, 103, 763-773. [CrossRef] [PubMed]

22. Bergstrom, A.; Hsieh, C.C.; Lindblad, P.; Lu, C.M.; Cook, N.R.; Wolk, A. Obesity and renal cell cancer-a quantitative review. Br. J. Cancer 2001, 85, 984-990. [CrossRef] [PubMed]

23. Liu, X.; Sun, Q.; Hou, H.; Zhu, K.; Wang, Q.; Liu, H.; Zhang, Q.; Ji, L.; Li, D. The association between BMI and kidney cancer risk: An updated dose-response meta-analysis in accordance with PRISMA guideline. Medicine (Baltimore) 2018, 97, e12860. [CrossRef] [PubMed]

24. Leiba, A.; Kark, J.D.; Afek, A.; Derazne, E.; Barchana, M.; Tzur, D.; Vivante, A.; Shamiss, A. Adolescent obesity and paternal country of origin predict renal cell carcinoma: A cohort study of 1.1 million 16 to 19-year-old males. J. Urol. 2013, 189, 25-29. [CrossRef] [PubMed]

25. Gati, A.; Kouidhi, S.; Marrakchi, R.; El Gaaied, A.; Kourda, N.; Derouiche, A.; Chebil, M.; Caignard, A.; Perier, A. Obesity and renal cancer: Role of adipokines in the tumor-immune system conflict. Oncoimmunology 2014, 3, e27810. [CrossRef] [PubMed]

26. Gavrila, A.; Chan, J.L.; Yiannakouris, N.; Kontogianni, M.; Miller, L.C.; Orlova, C.; Mantzoros, C.S. Serum adiponectin levels are inversely associated with overall and central fat distribution but are not directly regulated by acute fasting or leptin administration in humans: Cross-sectional and interventional studies. J. Clin. Endocrinol. Metab. 2003, 88, 4823-4831. [CrossRef]

27. Coppola, A.; Marfella, R.; Coppola, L.; Tagliamonte, E.; Fontana, D.; Liguori, E.; Cirillo, T.; Cafiero, M.; Natale, S.; Astarita, C. Effect of weight loss on coronary circulation and adiponectin levels in obese women. Int. J. Cardiol. 2009, 134, 414-416. [CrossRef]

28. Sugiyama, M.; Takahashi, H.; Hosono, K.; Endo, H.; Kato, S.; Yoneda, K.; Nozaki, Y.; Fujita, K.; Yoneda, M.; Wada, K.; et al. Adiponectin inhibits colorectal cancer cell growth through the AMPK/mTOR pathway. Int. J. Oncol. 2009, 34, 339-344.

29. Spyridopoulos, T.N.; Petridou, E.T.; Skalkidou, A.; Dessypris, N.; Chrousos, G.P.; Mantzoros, C.S.; Obesity; Cancer Oncology Group. Low adiponectin levels are associated with renal cell carcinoma: A case-control study. Int. J. Cancer 2007, 120, 1573-1578. [CrossRef]

30. Horiguchi, A.; Sumitomo, M.; Asakuma, J.; Asano, T.; Zheng, R.; Asano, T.; Nanus, D.M.; Hayakawa, M. Increased serum leptin levels and over expression of leptin receptors are associated with the invasion and progression of renal cell carcinoma. J. Urol. 2006, 176, 1631-1635. [CrossRef]

31. Liao, L.M.; Schwartz, K.; Pollak, M.; Graubard, B.I.; Li, Z.; Ruterbusch, J.; Rothman, N.; Davis, F.; Wacholder, S.; Colt, J.; et al. Serum leptin and adiponectin levels and risk of renal cell carcinoma. Obesity (Silver Spring) 2013, 21, 1478-1485. [CrossRef] [PubMed]

32. Horiguchi, A.; Sumitomo, M.; Asakuma, J.; Asano, T.; Zheng, R.; Asano, T.; Nanus, D.M.; Hayakawa, M. Leptin promotes invasiveness of murine renal cancer cells via extracellular signal-regulated kinases and rho dependent pathway. J. Urol. 2006, 176, 1636-1641. [CrossRef] [PubMed]

33. Li, L.; Gao, Y.; Zhang, L.L.; He, D.L. Concomitant activation of the JAK/STAT3 and ERK1/2 signaling is involved in leptin-mediated proliferation of renal cell carcinoma Caki-2 cells. Cancer Biol. 2008, 7, 1787-1792. [CrossRef] [PubMed]

34. Yokota, T.; Oritani, K.; Takahashi, I.; Ishikawa, J.; Matsuyama, A.; Ouchi, N.; Kihara, S.; Funahashi, T.; Tenner, A.J.; Tomiyama, Y.; et al. Adiponectin, a new member of the family of soluble defense collagens, negatively regulates the growth of myelomonocytic progenitors and the functions of macrophages. Blood 2000, 96, 1723-1732. [CrossRef] 
35. Gonzalez-Perez, R.R.; Xu, Y.; Guo, S.; Watters, A.; Zhou, W.; Leibovich, S.J. Leptin upregulates VEGF in breast cancer via canonic and non-canonical signalling pathways and NFkappaB/HIF-1alpha activation. Cell Signal. 2010, 22, 1350-1362. [CrossRef]

36. Solarek, W.; Koper, M.; Lewicki, S.; Szczylik, C.; Czarnecka, A.M. Insulin and insulin-like growth factors act as renal cell cancer intratumoral regulators. J. Cell Commun. Signal. 2019, 13, 381-394. [CrossRef]

37. Clarke, R.B.; Howell, A.; Anderson, E. Type I insulin-like growth factor receptor gene expression in normal human breast tissue treated with oestrogen and progesterone. Br. J. Cancer 1997, 75, 251-257. [CrossRef]

38. Kim, K.Y.; Kim, J.K.; Han, S.H.; Lim, J.S.; Kim, K.I.; Cho, D.H.; Lee, M.S.; Lee, J.H.; Yoon, D.Y.; Yoon, S.R.; et al. Adiponectin is a negative regulator of NK cell cytotoxicity. J. Immunol. 2006, 176, 5958-5964. [CrossRef]

39. Meijer, K.; de Vries, M.; Al-Lahham, S.; Bruinenberg, M.; Weening, D.; Dijkstra, M.; Kloosterhuis, N.; van der Leij, R.J.; van der Want, H.; Kroesen, B.J.; et al. Human primary adipocytes exhibit immune cell function: Adipocytes prime inflammation independent of macrophages. PLoS ONE 2011, 6, e17154. [CrossRef]

40. Grivennikov, S.I.; Karin, M. Inflammation and oncogenesis: A vicious connection. Curr. Opin. Genet. Dev. 2010, 20, 65-71. [CrossRef]

41. Hanahan, D.; Weinberg, R.A. Hallmarks of cancer: The next generation. Cell 2011, 144, 646-674. [CrossRef]

42. Ohno, Y.; Nakashima, J.; Ohori, M.; Hatano, T.; Tachibana, M. Pretreatment neutrophil-to-lymphocyte ratio as an independent predictor of recurrence in patients with nonmetastatic renal cell carcinoma. J. Urol. 2010, 184, 873-878. [CrossRef]

43. Waalkes, S.; Merseburger, A.S.; Kramer, M.W.; Herrmann, T.R.; Wegener, G.; Rustemeier, J.; Hofmann, R.; Schrader, M.; Kuczyk, M.A.; Schrader, A.J. Obesity is associated with improved survival in patients with organ-confined clear-cell kidney cancer. Cancer Causes Control 2010, 21, 1905-1910. [CrossRef] [PubMed]

44. Tsivian, E.; Tsivian, M.; Tay, K.J.; Longo, T.; Zukerman, Z.; Martorana, G.; Schiavina, R.; Brunocilla, E.; Polascik, T.J. Body mass index and the clinicopathological characteristics of clinically localized renal masses-An international retrospective review. Urol. Oncol. 2017, 35, 459.e1-459.e5. [CrossRef]

45. Albiges, L.; Hakimi, A.A.; Xie, W.; McKay, R.R.; Simantov, R.; Lin, X.; Lee, J.L.; Rini, B.I.; Srinivas, S.; Bjarnason, G.A.; et al. Body Mass Index and Metastatic Renal Cell Carcinoma: Clinical and Biological Correlations. J. Clin. Oncol. 2016, 34, 3655-3663. [CrossRef] [PubMed]

46. Hakimi, A.A.; Furberg, H.; Zabor, E.C.; Jacobsen, A.; Schultz, N.; Ciriello, G.; Mikklineni, N.; Fiegoli, B.; Kim, P.H.; Voss, M.H.; et al. An epidemiologic and genomic investigation into the obesity paradox in renal cell carcinoma. J. Natl. Cancer Inst. 2013, 105, 1862-1870. [CrossRef] [PubMed]

47. Chen, Y.; Patel, V.; Bang, S.; Cohen, N.; Millar, J.; Kim, S.F. Maturation and activity of sterol regulatory element binding protein 1 is inhibited by acyl-CoA binding domain containing 3. PLoS ONE 2012, 7, e49906. [CrossRef] [PubMed]

48. Griffiths, B.; Lewis, C.A.; Bensaad, K.; Ros, S.; Zhang, Q.; Ferber, E.C.; Konisti, S.; Peck, B.; Miess, H.; East, P.; et al. Sterol regulatory element binding protein-dependent regulation of lipid synthesis supports cell survival and tumor growth. Cancer Metab. 2013, 1, 3. [CrossRef] [PubMed]

49. Nguyen, P.L.; Ma, J.; Chavarro, J.E.; Freedman, M.L.; Lis, R.; Fedele, G.; Fiore, C.; Qiu, W.; Fiorentino, M.; Finn, S.; et al. Fatty acid synthase polymorphisms, tumor expression, body mass index, prostate cancer risk, and survival. J. Clin. Oncol. 2010, 28, 3958-3964. [CrossRef] [PubMed]

50. Renfro, L.A.; Loupakis, F.; Adams, R.A.; Seymour, M.T.; Heinemann, V.; Schmoll, H.J.; Douillard, J.Y.; Hurwitz, H.; Fuchs, C.S.; Diaz-Rubio, E.; et al. Body Mass Index Is Prognostic in Metastatic Colorectal Cancer: Pooled Analysis of Patients From First-Line Clinical Trials in the ARCAD Database. J. Clin. Oncol. 2016, 34, 144-150. [CrossRef]

51. Moyad, M.A. Obesity, interrelated mechanisms, and exposures and kidney cancer. Semin. Urol. Oncol. 2001, 19, 270-279. [PubMed]

52. Steffens, S.; Grunwald, V.; Ringe, K.I.; Seidel, C.; Eggers, H.; Schrader, M.; Wacker, F.; Kuczyk, M.A.; Schrader, A.J. Does obesity influence the prognosis of metastatic renal cell carcinoma in patients treated with vascular endothelial growth factor-targeted therapy? Oncologist 2011, 16, 1565-1571. [CrossRef] [PubMed]

53. Solarek, W.; Czarnecka, A.M.; Escudier, B.; Bielecka, Z.F.; Lian, F.; Szczylik, C. Insulin and IGFs in renal cancer risk and progression. Endocr. Relat. Cancer 2015, 22, R253. [CrossRef] [PubMed]

54. Gatica, R.; Bertinat, R.; Silva, P.; Carpio, D.; Ramirez, M.J.; Slebe, J.C.; San Martin, R.; Nualart, F.; Campistol, J.M.; Caelles, C.; et al. Altered expression and localization of insulin receptor in proximal tubule cells from human and rat diabetic kidney. J. Cell Biochem. 2013, 114, 639-649. [CrossRef] 
55. Matyszewski, A.; Czarnecka, A.; Kawecki, M.; Korzen, P.; Safir, I.J.; Kukwa, W.; Szczylik, C. Impaired glucose metabolism treatment and carcinogenesis. Oncol. Lett. 2015, 10, 589-594. [CrossRef]

56. Reuveni, H.; Flashner-Abramson, E.; Steiner, L.; Makedonski, K.; Song, R.; Shir, A.; Herlyn, M.; Bar-Eli, M.; Levitzki, A. Therapeutic destruction of insulin receptor substrates for cancer treatment. Cancer Res. 2013, 73, 4383-4394. [CrossRef]

57. Pollak, M. Insulin and insulin-like growth factor signalling in neoplasia. Nat. Rev. Cancer 2008, 8, 915-928. [CrossRef]

58. Ibrahim, Y.H.; Yee, D. Insulin-like growth factor-I and cancer risk. Growth Horm. IGF Res. 2004, 14, $261-269$. [CrossRef]

59. Li, Y.L.; Zhao, H.; Ren, X.B. Relationship of VEGF/VEGFR with immune and cancer cells: Staggering or forward? Cancer Biol. Med. 2016, 13, 206-214. [CrossRef]

60. Zhang, T.; Niu, X.; Liao, L.; Cho, E.-A.; Yang, H. The contributions of HIF-target genes to tumor growth in RCC. PLoS ONE 2013, 8, e80544. [CrossRef]

61. Johansson, M.; Carreras-Torres, R.; Scelo, G.; Purdue, M.P.; Mariosa, D.; Muller, D.C.; Timpson, N.J.; Haycock, P.C.; Brown, K.M.; Wang, Z.; et al. The influence of obesity-related factors in the etiology of renal cell carcinoma-A mendelian randomization study. PLoS Med. 2019, 16, e1002724. [CrossRef]

62. Frasca, F.; Pandini, G.; Sciacca, L.; Pezzino, V.; Squatrito, S.; Belfiore, A.; Vigneri, R. The role of insulin receptors and IGF-I receptors in cancer and other diseases. Arch. Physiol. Biochem. 2008, 114, $23-37$. [CrossRef] [PubMed]

63. Frystyk, J. Free insulin-like growth factors-Measurements and relationships to growth hormone secretion and glucose homeostasis. Growth Horm. IGF Res. 2004, 14, 337-375. [CrossRef] [PubMed]

64. Belfiore, A.; Malaguarnera, R. Insulin receptor and cancer. Endocr. Relat. Cancer 2011, 8, R125-R147. [CrossRef] [PubMed]

65. Takahashi, M.; Inoue, T.; Huang, M.; Numakura, K.; Tsuruta, H.; Saito, M.; Maeno, A.; Nakamura, E.; Narita, S.; Tsuchiya, N.; et al. Inverse relationship between insulin receptor expression and progression in renal cell carcinoma. Oncol. Rep. 2017, 37, 2929-2941. [CrossRef] [PubMed]

66. Rasmuson, T.; Grankvist, K.; Jacobsen, J.; Olsson, T.; Ljungberg, B. Serum insulin-like growth factor-1 is an independent predictor of prognosis in patients with renal cell carcinoma. Acta Oncol. 2004, 43, 744-748. [CrossRef]

67. Lindblad, P.; Chow, W.H.; Chan, J.; Bergstrom, A.; Wolk, A.; Gridley, G.; McLaughlin, J.K.; Nyren, O.; Adami, H.O. The role of diabetes mellitus in the aetiology of renal cell cancer. Diabetologia 1999, 42, 107-112. [CrossRef]

68. Zucchetto, A.; Dal Maso, L.; Tavani, A.; Montella, M.; Ramazzotti, V.; Talamini, R.; Canzonieri, V.; Garbeglio, A.; Negri, E.; Franceschi, S.; et al. History of treated hypertension and diabetes mellitus and risk of renal cell cancer. Ann. Oncol. 2007, 18, 596-600. [CrossRef]

69. Habib, S.L.; Prihoda, T.J.; Luna, M.; Werner, S.A. Diabetes and risk of renal cell carcinoma. J. Cancer 2012, 3, 42-48. [CrossRef]

70. Kosti, A.; Harry Chen, H.I.; Mohan, S.; Liang, S.; Chen, Y.; Habib, S.L. Microarray profile of human kidney from diabetes, renal cell carcinoma and renal cell carcinoma with diabetes. Genes Cancer 2015, 6, 62-70. [CrossRef]

71. Linehan, W.M.; Ricketts, C.J. The metabolic basis of kidney cancer. Semin. Cancer Biol. 2013, 23 , 46-55. [CrossRef] [PubMed]

72. Duan, W.; Shen, X.; Lei, J.; Xu, Q.; Yu, Y.; Li, R.; Wu, E.; Ma, Q. Hyperglycemia, a neglected factor during cancer progression. BioMed Res. Int. 2014, 2014, 461917. [CrossRef] [PubMed]

73. Ryu, T.Y.; Park, J.; Scherer, P.E. Hyperglycemia as a risk factor for cancer progression. Diabetes Metab. J. 2014, 38, 330-336. [CrossRef] [PubMed]

74. Habib, S.L.; Liang, S. Hyperactivation of Akt/mTOR and deficiency in tuberin increased the oxidative DNA damage in kidney cancer patients with diabetes. Oncotarget 2014, 5, 2542-2550. [CrossRef] [PubMed]

75. Li, M.; Liu, J.; Hu, W.L.; Jia, C.H.; Li, H.Y.; Wen, Z.H.; Zou, Z.P.; Bai, X.C.; Luo, S.Q. Effect of metformin on apoptosis of renal cell carcinoma cells in vitro and its mechanisms. Nan Fang Yi Ke Da Xue Xue Bao 2011, 31, 1504-1508.

76. Liu, J.; Li, M.; Song, B.; Jia, C.; Zhang, L.; Bai, X.; Hu, W. Metformin inhibits renal cell carcinoma in vitro and in vivo xenograft. Urol. Oncol. 2013, 31, 264-270. [CrossRef] 
77. Landman, G.W.; Kleefstra, N.; van Hateren, K.J.; Groenier, K.H.; Gans, R.O.; Bilo, H.J. Metformin associated with lower cancer mortality in type 2 diabetes: ZODIAC-16. Diabetes Care 2010, 33, 322-326. [CrossRef]

78. Lee, S.; Hong, S.K.; Kwak, C.; Kim, H.H.; Lee, S.E. Prognostic Significance of Diabetes Mellitus in Localized Renal Cell Carcinoma. Jpn. J. Clin. Oncol. 2012, 42, 318-324. [CrossRef]

79. Graff, R.E.; Sanchez, A.; Tobias, D.K.; Rodriguez, D.; Barrisford, G.W.; Blute, M.L.; Li, Y.; Sun, Q.; Preston, M.A.; Wilson, K.M.; et al. Type 2 Diabetes in Relation to the Risk of Renal Cell Carcinoma Among Men and Women in Two Large Prospective Cohort Studies. Diabetes Care 2018, 41, 1432-1437. [CrossRef]

80. Bao, C.; Yang, X.; Xu, W.; Luo, H.; Xu, Z.; Su, C.; Qi, X. Diabetes mellitus and incidence and mortality of kidney cancer: A meta-analysis. J. Diabetes Complicat. 2013, 27, 357-364. [CrossRef]

81. Nicodemus, K.K.; Sweeney, C.; Folsom, A.R. Evaluation of dietary, medical and lifestyle risk factors for incident kidney cancer in postmenopausal women. Int. J. Cancer 2004, 108, 115-121. [CrossRef] [PubMed]

82. Lee, J.E.; Hankinson, S.E.; Cho, E. Reproductive factors and risk of renal cell cancer: The Nurses' Health Study. Am. J. Epidemiol. 2009, 169, 1243-1250. [CrossRef] [PubMed]

83. Lee, H.; Kwak, C.; Kim, H.H.; Byun, S.S.; Lee, S.E.; Hong, S.K. Diabetes Mellitus as an Independent Predictor of Survival of Patients Surgically Treated for Renal Cell Carcinoma: A Propensity Score Matching Study. J. Urol. 2015, 194, 1554-1560. [CrossRef] [PubMed]

84. Vavallo, A.; Simone, S.; Lucarelli, G.; Rutigliano, M.; Galleggiante, V.; Grandaliano, G.; Gesualdo, L.; Campagna, M.; Cariello, M.; Ranieri, E.; et al. Pre-existing type 2 diabetes mellitus is an independent risk factor for mortality and progression in patients with renal cell carcinoma. Medicine (Baltimore) 2014, 93 , e183. [CrossRef]

85. Fukushima, H.; Masuda, H.; Yokoyama, M.; Tatokoro, M.; Yoshida, S.; Ishioka, J.; Matsuoka, Y.; Numao, N.; Koga, F.; Saito, K.; et al. Diabetes mellitus with obesity is a predictor of recurrence in patients with non-metastatic renal cell carcinoma. Jpn. J. Clin. Oncol. 2013, 43, 740-746. [CrossRef]

86. Wulaningsih, W.; Garmo, H.; Holmberg, L.; Hammar, N.; Jungner, I.; Walldius, G.; Van Hemelrijck, M. Serum Lipids and the Risk of Gastrointestinal Malignancies in the Swedish AMORIS Study. J. Cancer Epidemiol. 2012, 2012, 792034. [CrossRef]

87. Inoue, M.; Noda, M.; Kurahashi, N.; Iwasaki, M.; Sasazuki, S.; Iso, H.; Tsugane, S.; Japan Public Health Center-Based Prospective Study Group. Impact of metabolic factors on subsequent cancer risk: Results from a large-scale population-based cohort study in Japan. Eur. J. Cancer Prev. 2009, 18, 240-247. [CrossRef]

88. Zhang, G.M.; Zhu, Y.; Luo, L.; Zhang, H.L.; Gu, C.Y.; Sun, L.J.; Ye, D.W. Prevalence of dyslipidaemia in patients with renal cell carcinoma: A case-control study in China. BJU Int. 2014, 113, E75-E81. [CrossRef]

89. Bowers, K.; Albanes, D.; Limburg, P.; Pietinen, P.; Taylor, P.R.; Virtamo, J.; Stolzenberg-Solomon, R. A prospective study of anthropometric and clinical measurements associated with insulin resistance syndrome and colorectal cancer in male smokers. Am. J. Epidemiol. 2006, 164, 652-664. [CrossRef]

90. Asano, K.; Kubo, M.; Yonemoto, K.; Doi, Y.; Ninomiya, T.; Tanizaki, Y.; Arima, H.; Shirota, T.; Matsumoto, T.; Iida, M.; et al. Impact of serum total cholesterol on the incidence of gastric cancer in a population-based prospective study: The Hisayama study. Int. J. Cancer 2008, 122, 909-914. [CrossRef]

91. Eichholzer, M.; Stahelin, H.B.; Gutzwiller, F.; Ludin, E.; Bernasconi, F. Association of low plasma cholesterol with mortality for cancer at various sites in men: 17-y follow-up of the prospective Basel study. Am. J. Clin. Nutr. 2000, 71, 569-574. [CrossRef] [PubMed]

92. Panagiotakos, D.B.; Pitsavos, C.; Polychronopoulos, E.; Chrysohoou, C.; Menotti, A.; Dontas, A.; Stefanadis, C. Total cholesterol and body mass index in relation to 40-year cancer mortality (the Corfu cohort of the seven countries study). Cancer Epidemiol. Biomark. Prev. 2005, 14, 1797-1801. [CrossRef] [PubMed]

93. Brock, K.E.; Gridley, G.; Chiu, B.C.; Ershow, A.G.; Lynch, C.F.; Cantor, K.P. Dietary fat and risk of renal cell carcinoma in the USA: A case-control study. Br. J. Nutr. 2009, 101, 1228-1238. [CrossRef]

94. Andreotti, G.; Chen, J.; Gao, Y.T.; Rashid, A.; Chang, S.C.; Shen, M.C.; Wang, B.S.; Han, T.Q.; Zhang, B.H.; Danforth, K.N.; et al. Serum lipid levels and the risk of biliary tract cancers and biliary stones: A population-based study in China. Int. J. Cancer 2008, 122, 2322-2329. [CrossRef] [PubMed]

95. Zhang, C.; Yu, L.; Xu, T.; Hao, Y.; Zhang, X.; Liu, Z.; Xiao, Y.; Wang, X.; Zeng, Q. Association of dyslipidemia with renal cell carcinoma: A 1ratio2 matched case-control study. PLoS ONE 2013, 8, e59796. [CrossRef]

96. Nofer, J.R.; Junker, R.; Pulawski, E.; Fobker, M.; Levkau, B.; von Eckardstein, A.; Seedorf, U.; Assmann, G.; Walter, M. High density lipoproteins induce cell cycle entry in vascular smooth muscle cells via mitogen activated protein kinase-dependent pathway. Thromb. Haemost. 2001, 85, 730-735. 
97. Nofer, J.R.; Levkau, B.; Wolinska, I.; Junker, R.; Fobker, M.; von Eckardstein, A.; Seedorf, U.; Assmann, G. Suppression of endothelial cell apoptosis by high density lipoproteins (HDL) and HDL-associated lysosphingolipids. J. Biol. Chem. 2001, 276, 34480-34485. [CrossRef]

98. Von Eckardstein, A.; Hersberger, M.; Rohrer, L. Current understanding of the metabolism and biological actions of HDL. Curr. Opin. Clin. Nutr. Metab. Care 2005, 8, 147-152. [CrossRef]

99. Benn, M.; Tybjaerg-Hansen, A.; Stender, S.; Frikke-Schmidt, R.; Nordestgaard, B.G. Low-density lipoprotein cholesterol and the risk of cancer: A mendelian randomization study. J. Natl. Cancer Inst. 2011, 103, 508-519. [CrossRef]

100. Ahn, J.; Lim, U.; Weinstein, S.J.; Schatzkin, A.; Hayes, R.B.; Virtamo, J.; Albanes, D. Prediagnostic total and high-density lipoprotein cholesterol and risk of cancer. Cancer Epidemiol. Biomark. Prev. 2009, 18, $2814-2821$. [CrossRef]

101. Du, Y.Q.; Liu, H.X.; Liu, C.L.; Dun, Y.J.; Li, Q.; Yu, L.P.; Liu, S.J.; Chen, L.L.; Wang, X.F.; Xu, T. Analysis of metabolic factors and relevance with the grade and stage in patients with renal cell carcinoma. Beijing Da Xue Xue Bao Yi Xue Ban 2016, 48, 612-617. [PubMed]

102. Horiguchi, A.; Sumitomo, M.; Asakuma, J.; Asano, T.; Asano, T.; Hayakawa, M. 3-hydroxy-3-methylglutaryl-coenzyme a reductase inhibitor, fluvastatin, as a novel agent for prophylaxis of renal cancer metastasis. Clin. Cancer Res. 2004, 10, 8648-8655. [CrossRef] [PubMed]

103. Petruzzelli, M.; Wagner, E.F. Mechanisms of metabolic dysfunction in cancer-associated cachexia. Genes Dev. 2016, 30, 489-501. [CrossRef] [PubMed]

104. Kawakami, M.; Cerami, A. Studies of endotoxin-induced decrease in lipoprotein lipase activity. J. Exp. Med. 1981, 154, 631-639. [CrossRef] [PubMed]

(C) 2020 by the authors. Licensee MDPI, Basel, Switzerland. This article is an open access article distributed under the terms and conditions of the Creative Commons Attribution (CC BY) license (http://creativecommons.org/licenses/by/4.0/). 